\title{
GUERRAS E REFUGIADOS: UMA RELAÇÃO GEOESTRATÉGICA
}

Fábio Júnior da Luz Barros ${ }^{1}$

Nadson Vinicius dos Santos ${ }^{2}$

\begin{abstract}
Resumo: O presente artigo objetiva refletir sobre a questão dos refugiados de guerra provenientes da Síria e Afeganistão em direção à Europa no início do Século XXI. Os países citados acima estão localizados em pontos geoestratégicos militar e economicamente. Este artigo, portanto, se justifica por apresentar a complexidade das questões envolvendo os refugiados desses episódios bélicos. O texto é de cunho qualitativo baseado em pesquisas bibliográficas: livros (OLIVEIRA, 2017), dissertação (JUNSKOWSKI, 2017), tese (DOS SANTOS, 2017), além de estatutos, legislação, cinema, dentre outros. Mediante tais dados, o artigo evidencia como as leis sobre refúgio mudam de acordo ao contexto histórico e conforme a procedência e destino dos migrantes. O escrito está dividido em três seções que tratam da resistência afegã e síria perante o imperialismo ocidental ao longo dos séculos e da criação do Estatuto dos Refugiados assinado em 1951, sobretudo, a respeito da lei "no refoulement" e de como a geopolítica de países da Europa, Rússia e os Estados Unidos da América influenciam nessa problemática.

Palavras chave: Refugiados. Legislação. Síria. Afeganistão. Geopolítica.
\end{abstract}

\section{WARS AND REFUGEES: A GEOSTRATEGIC RELATIONSHIP}

\begin{abstract}
This article aims to reflect on the issue of war refugees from Syria and Afghanistan towards Europe at the beginning of the 21 st century. The countries mentioned above are located at geostrategic points militarily and economically. This article, therefore, is justified by presenting the complexity of the issues involving refugees from these war episodes. The text is of a qualitative nature based on bibliographic research: books (OLIVEIRA, 2017), dissertation (JUNSKOWSKI, 2017), thesis (DOS SANTOS, 2017), in addition to statutes, legislation, cinema, among others. Based on such data, the article shows how the laws on refuge change according to the historical context and according to the origin and destination of migrants. The writing is divided into three sections dealing with Afghan and Syrian resistance to Western imperialism over the centuries and the creation of the Refugee Statute signed in 1951, above all, regarding the law "no refoulement" and how the geopolitics of countries Europe, Russia and the United States of America influence this issue.
\end{abstract}

Keywords: Refugees. Legislation. Syria. Afghanistan. Geopolitics.

\section{Introdução}

Nas primeiras duas décadas do século XXI, cresceu o fluxo migratório de pessoas em todo o globo, sobretudo, no norte da África e Oriente Médio em direção ao continente europeu. Esses níveis de mobilidade territorial da população aumentaram significativamente, oriundos principalmente da Síria e Afeganistão, países localizados no Oriente Médio, região da Ásia Ocidental. Ao longo do presente escrito, demostrarei em números a migração de pessoas saindo dos países citados em direção à Europa. Vale ressaltar que, neste artigo, tratarei das causas e consequências das migrações provindas de conflitos militares na região do Oriente Médio, precisamente, da Síria e Afeganistão. Observo tal questão excluindo as migrações causadas por fome e/ou geradas por fatores naturais, bem como por oscilações no mercado financeiro.

\footnotetext{
${ }^{1}$ Discente do programa de Pós-Graduação Stricto Sensu- Mestrando em Estado e Sociedade- Universidade Federal do Sul da Bahia- UFSB. Graduado no curso de Bacharel em Geografia oferecido pela Universidade Estadual de Santa Cruz- UESC.

${ }^{2}$ Formado em Letras/espanhol pela Universidade Estadual de Santa cruz (UESC) e mestre pela mesma instituição no PPGL: Linguagens e representações. Doutor pela universidade federal do Rio grande (FURG). Atualmente, professor de português/espanhol no Instituto Federal Goiano (IFGoiano).
} 
A Ásia Ocidental foi historicamente palco de guerras, espoliação, impérios, conquistas e migrações. Oliveira et al. (2017, p.74), explica que "os fluxos de refugiados, com maior ou menor intensidade, permanecem como uma dimensão estrutural das migrações para a (e na) Europa nas últimas sete décadas". Com base nessa acepção, os movimentos migratórios do início do século XXI são similares desde o pós-guerra, quando, ainda segundo Oliveira et al. (p.76), estima-se que "tenha havido cerca de 60 milhões de deslocados".

A migração e o direito a refúgio em outras nações começaram a ser debatidos juridicamente após a Segunda Guerra mundial, ocorrida entre 1939-1945. Os debates levaram à aprovação d'O Estatuto dos Refugiados, tal como adotado a 28 de julho de 1951. Entrou em vigor em abril de 1954 como parte da Declaração Universal dos Direitos do Homem - 1948. Sendo assim, este estatuto assegura o: "direito de qualquer pessoa perseguida em seu Estado a solicitar proteção a outro Estado, mas não estabelece o dever de um Estado conceder asilo (JUBILUT, 2007, p. 36).

A migração é um fenômeno trivial no planeta, visto que a sociedade humana nunca foi estática e nunca o será. Desde os primórdios, as pessoas se movimentam pelo globo à procura de comida; melhores abrigos, fugindo de sistemas ditatoriais, catástrofes naturais, dentre outras causas. Entretanto, há evidências de que as migrações e os refúgios dos dias atuais têm outras peculiaridades, a maioria dos migrantes não se preocupam em fugir de seus países por conta dos temores endógenos, na verdade, são temores exógenos que implantam o caos e a turbulência à procura de fontes energéticas e, consequentemente, poder e riqueza. ${ }^{3}$

O presente texto discute somente questões históricas a respeito dos conflitos nos territórios afegão e sírio, bem como, a migração decorrente desses episódios. Não pretendo aqui adentrar o mérito geopolítico da região nem esgotar o assunto no trabalho ora apresentado. A discussão teórica gira em torno da história das invasões do território afegão e sírio, das leis dos refugiados e da influência na região das nações que formam o conselho de segurança da ONU.

\section{Uma História Social das Guerras no Território do Afeganistão}

O território Afegão resistiu a diversos tipos de investidas. A começar pelo império de Ciro, o Grande (530 a.C.), o qual primeiro menciona o Afeganistão, mas ainda como pequenos vilarejos; o que também se verificou no império de Dário, o Grande (550-486 a.C.) e, por fim, Alexandre Magno (330-323 a.C.), que conquistou com o exército grego o Afeganistão e a Ásia Central; porém, não demorou muito para perder este território para o império mongol.

\footnotetext{
${ }^{3}$ Para maiores aprofundamentos consultar: HARVEY, David. O Novo Imperialismo. 8. ed. São Paulo: Edições Loyola, 2014.
} 
Segundo Baptista (2003, p. 6): “após a queda do Império Mongol, precipita-se a colonização da Índia, levando a lutas entre Franceses, Ingleses e o Império Russo que procurava uma saída para o Oceano Índico". O autor segue dizendo que é:

neste contexto, que se enquadram as três guerras Anglo-afegãs. A primeira guerra (1839-1842) foi um fracasso para o Reino Unido que tentou importar o seu estilo colonial no país, suscitando uma insurreição armada. A segunda guerra com o Reino Unido, que surgiu devido a um conflito de influências entre Ingleses e Russos no Afeganistão, terminava em 1879 com o tratado de Gandamak. Este permitiu aos Ingleses a instalação de uma delegação permanente em Cabul e a orientação da política externa afegã segundo o seu princípio (BAPTISTA, 2003, p.6).

As contínuas tensões entre Rússia ${ }^{4}$ e Inglaterra seguem até a Primeira Guerra mundial, todavia, nesse ínterim, estes fazem muitos acordos e dividem o território afegão em duas partes entre si, desrespeitando totalmente as leis territoriais, culturais, dentre outras questões intrínsecas ao território, causando um caos no interior desta civilização. Entretanto, houve um desentendimento entre Rússia e Inglaterra, diante disto, o Afeganistão torna-se colônia do império da Grã-Bretanha.

O líder político afegão Emir Habib Allah ficou célebre pelo seu sucesso em manter a GrãBretanha e a Rússia afastadas e preservar a independência e a neutralidade do Afeganistão durante a primeira Guerra Mundial. Após a sua morte em 1919, desencadeia-se a terceira guerra Anglo-afegã, que termina com o Tratado de Rawalpindi em agosto de 1919, reconhecendo a independência do Afeganistão. A revolução Russa afasta o Afeganistão do círculo de poder Inglês, mas ocidentaliza depressa setores importantes da sociedade afegã, o que resultou na resistência interna de membros dos conselhos mais tradicionais do país. Na maior parte do século XX, o Afeganistão foi parceiro da União Soviética, mesmo durante seu período monarquista. Os soviéticos tinham um papel muito significativo na economia afegã, fornecendo ajuda humanitária, além de auxiliar com armamentos, treinamento militar e desenvolvimento de infraestrutura.

A década de 1970, contudo, surpreendeu a monarquia local com um golpe de estado e levou Mohammed Daoud Khan à presidência do país. No entanto, a aproximação Soviética legou ao país a ideologia comunista e partidos de base socialista e operário, o mais famoso, intitulado Partido Democrático do Povo Afegão (PDPA), organizou um golpe contra o presidente recém empossado em abril de 1978.

\footnotetext{
${ }^{4}$ Vale ressaltar que nesse artigo quando menciono a Rússia, refiro-me a Eurásia da Europa, o que é simbolizado pela a águia de duas cabeças no seu brasão, ou seja, o seu território pertence a dois continentes.
} 
Os episódios tratam de invasão da casa presidencial e morte de 18 integrantes da família do presidente. Desse modo, Nur Muhammad Taraki tomou o poder no Afeganistão. Esse processo ficou conhecido como Revolução de Saur. Com o poder, o novo presidente iniciou uma reforma agrária, promoveu o ensino laico e viabilizou a participação feminina na agenda política. Essas ideias não agradaram aos conservadores. A insatisfação tornou-se uma rebelião quando esses grupos pegaram em armas e começaram a se levantar contra o então governo. Nesse dado momento, dentro do Partido Democrático do Povo Afegão (PDPA), houve um racha e o presidente recebeu um golpe militar e foi deposto, o seu sucessor foi Hafizullah Amin, que mostrou desgaste com seu maior aliado, a União Soviética. Nas décadas de 1970 aconteceram três golpes de estado no Afeganistão.

A ajuda soviética em um desses golpes levou o país a invadir o Afeganistão, haja vista os soviéticos julgarem uma aproximação entre aquele e os Estado Unidos da América. Diante disto, os mujahidin (combatentes afegãos) convocaram uma guerra santa contra os Soviéticos. Essa guerra durou dez anos. Por um lado, a União Soviética apoiava o governo afegão, enquanto os norte-americanos asseguravam os rebeldes com inteligência militar e, sobretudo, armas.

A União Soviética perdeu a guerra por questões financeiras, estima-se que foram gastos 2,6 bilhões ${ }^{5}$ de dólares durante os dez anos de confronto. Diante disto, em 1986, ela foi obrigada a assinar um acordo de retirada das tropas do território afegão, tal retirada perdurou até 1989, e em 1992 o presidente do Afeganistão sem apoio dos soviéticos perde a batalha definitivamente para os mujahidin.

Os rebeldes mujahidin deram origem a dois grupos fundamentalistas no território afegão: $\mathrm{Al}$ Qaeda e Talibã. Em 2001 esses grupos se envolveram no ataque às torres gêmeas nos Estados Unidos da América, o qual ocorreu no dia 11 de setembro, comandado segundo governo norte americano, por Osama Bin Laden, um ex mujahidin e chefe da AlQaeda. O então presidente dos Estados Unidos da América, George W. Bush, investiu um ataque juntamente com a OTANOrganização do Tratado do Atlântico Norte - e Rússia, com o álibi de que o Talibãa, governo vigente do Afeganistão, estava acobertando a Al Qaeda ${ }^{6}$ dentro do Território afegão. Esse ataque gerou uma onda de pedido de refúgio muito grande para a própria Europa. Segundo Oliveira et al (2017, p.83) "entre os 1.046 .599 indivíduos entrados na Europa em 2015 com pedido de refúgio, $(20,2 \%)$ era oriundo do Afeganistão".

\footnotetext{
${ }^{5}$ Dados retirados do site: < https://brasilescola.uol.com.br/guerras/ocupacao-sovietica-afeganistao.htm $>$.

${ }^{6}$ A Al Qaeda (ou "A Base”, em árabe) é uma organização militar fundada por Osama Bin Laden (1957-2011), em 1988, após o Afeganistão enfrentar uma guerra de nove anos contra a União Soviética. Esses guerrilheiros que já atuarram ao lado dos EUA e recebeu treinamento da Agência Central de Inteligência - CIA na guerra contra a União Soviética entre 1979 e1989.
} 
Os ataques desmoralizaram as instituições afegãs, e assim, a sociedade civil continuou sofrendo mesmo após a guerra e morte de Osama Bin Laden, ex-presidente da Al Qaeda, acusado de terrorismo e morto durante a gestão do presidente estadunidense Barack Obama.

\section{Uma História Social dos Conflitos em Território Sírio}

A Síria é um país localizado no Oriente Médio. Uma parte do território fica próximo ao Mar Mediterrâneo, onde vive 50\% da população. O restante do território nacional é tomado por um grande deserto, este possui reservas consideráveis de petróleo e, também, uma grande quantidade de gás natural. Vimos que há dois pontos fundamentais que são: primeiro, a saída para o mar e; segundo, as reservas imensas de petróleo e gás natural. Toda essa região já esteve sob o domínio de grandes impérios, entre eles, os persas, os gregos e os romanos. Durante os primeiros séculos da Era Cristã, a região passou ao controle do Império Romano do Oriente depois da divisão efetuada no século IV da era cristã. Em seguida, chegaram os Árabes (mulçumanos) no século VII, os Sunitas e os Xiitas, então, surgiram as Cruzadas sob o comando da instituição igreja católica sob os auspícios de reconquistar as terras santas e beatificá-las.

No entanto, os interesses verdadeiros era expandir o poder ocidental a outros territórios, ou seja, foi uma tentativa do ocidente, agora cristão, usurpar essas terras. Por fim chegaram os turcos e conquistam a região; fundando o Império Otomano, do qual este território fez parte até a Primeira Guerra Mundial (1914-1918). Após esse período, vários países se formaram naquela região, inclusive a Síria atual, que ficou sob controle militar da França e da Inglaterra. Nesse contexto, algumas nações foram desmembradas e/ou criadas, tudo segundo os caprichos da política europeia, como é de praxe historicamente. E assim:

a Síria é um país cujas fronteiras foram artificialmente traçadas de acordo com os interesses ocidentais (especialmente, franceses e britânicos) após a Primeira Guerra Mundial, e enfrenta há mais de seis anos um conflito travado entre diversas forças internas e externas, que em última instância pretendem levar à fragmentação do território sírio (SILVA; SILVA, 2018, p.80).

Na Síria, desde 2011, está havendo uma guerra que envolve grandes nações dentro do seu território, que arrogam o pretexto de combate ao terrorismo, porém, segundo Junskowski (2017, p. 37), terrorismo é um termo muito complexo, pois, “[...] nomear um grupo ou ação utilizando o termo terrorismo, pressupõe julgamento moral e pode ser usado a partir de interesses ideológicos e políticos para depreciar um indivíduo ou coletivo". O conflito que estamos assistindo na Síria, 
desde de 2011, foi travado por interesses de dois grandes grupos que nunca deixaram a guerra fria $^{7}$ : Rússia e Estados Unidos da América, juntamente com seus os aliados.

Os pressupostos dessa guerra civil travada no território sírio têm como caráter precípuo o combate ao terrorismo, mas na verdade, são interesses geopolíticos e geoestratégicos. Silva;Silva (2018), afirma que o Geógrafo Nicholas John Spykman, na Teoria do Rimland, inspirada na teoria do heartland, fala que a nação que controlar essa parte do globo, o Oriente Médio, situado na Ásia Ocidental, comandará várias passagens geoestratégicas que ligam o globo e, estas, são importantes para traçar rotas comercias e táticas militares. No caso do território sírio, este tem saída tanto para o mar mediterrâneo quanto para o continente e todas suas saídas são estratégicas, além disso, o país é riquíssimo em petróleo e gás natural, sobretudo, na região desértica. Essas brigas pelo poder e controle das regiões são responsáveis por fazer vários cidadãos migrarem e pedirem refúgios em outros territórios para morar e viver dignamente.

Oliveira et al. (2017, p. 83), evidencia que "entre os 1.046 .599 indivíduos entrados em 2015, metade $(50,2 \%)$ provinha da Síria". E a autora segue dizendo que: "entre as causas destes movimentos recentes para a Europa, estão os conflitos nos países vizinhos, mas não se esgotam neles" Oliveira et al. (2017, p. 83).

\section{Imigração: Entre a Lei e a Guerra}

A emigração dos sírios e afegãos mostra que todas as crises recentes estão intrinsicamente relacionadas às grandes potências econômicas. Esses conflitos geram mortes, segregações de famílias e, consequentemente, espoliações de pessoas. Segundo Harvey (2014), no seu livro intitulado "O Novo Imperialismo", muito embora essa obra trate, principalmente, das questões relacionadas ao império norte-americano, não deixa de ser útil para analisar as causas das guerras no Oriente Médio, provocadas, sobretudo, pelo interesse das grandes nações econômicas em controlar as regiões detentoras de petróleo.

A relação entre guerra e migração encontra um precedente interessante logo após a Segunda Guerra Mundial, quando os fluxos migratórios procedentes de toda a Europa sentido às Américas aumentaram muito. Os pedidos de refúgio provenientes desse continente continuaram em níveis de oscilações até os anos de 1990; os dados se acentuam na época da queda do Muro de Berlin (1989), instituindo o fim a União das Repúblicas Socialistas Soviéticas - URSS, isso porque alguns países como a Eslovênia, a Croácia, a Bósnia e a Herzegovina, ainda tentavam

\footnotetext{
${ }^{7}$ A Guerra Fria, que teve seu início logo após a Segunda Guerra Mundial (1945) e a extinção da União Soviética (1991), é a designação atribuída ao período histórico de disputas estratégicas e conflitos indiretos entre os Estados Unidos e a União Soviética, disputando a hegemonia política, econômica e militar no mundo. Disponível em < https:< https://www.politize.com.br/guerra-fria/>. Acessado em: 19/01/2020.
} 
organizar os seus territórios e suas independências, procurando, desse modo, se desligar da Iugoslávia.

Os europeus resolveram criar e negociar leis para facilitar a migração de seus cidadãos no pós-guerra, então, em 1951, na Convenção das Nações Unidas sobre o Estatuto dos Refugiados, ficou decretado que refugiado era:

toda pessoa que tendo um temor bem fundado de ser perseguida por motivos de raça, religião, nacionalidade, grupo social ou opiniões políticas, que se encontra fora do país de sua nacionalidade e que não pode ou, em virtude desse temor, não quer valer-se da proteção deste país, ou que, se não tem nacionalidade e se encontra fora do país no qual tinha a sua residência habitual em consequência de tais acontecimentos, não pode ou, devido ao referido temor, não quer voltar a $\mathrm{ele}^{8}\left(\operatorname{art}^{\mathrm{o}} 1\right)$

As leis dos refugiados privilegiaram, especialmente, a população dos países mais atingidos pela Segunda Guerra Mundial, ou seja, foram criadas no contexto da emigração dos europeus e não da imigração dos africanos ou asiáticos. Atualmente, esse estatuto está em discussão em diversos países, especialmente, nos países mais ricos, uma vez que muitos destes já acenam que irão sair do acordo relacionado às questões dos pedidos de refúgio presentes no estatuto. Exemplo desses países são a Polônia, a Hungria, dentre outros ${ }^{9}$.

O intuito de reforçar a importância do refúgio, fez a Europa aprovar, por exemplo, o Tratado de Lisboa, assinado em 2009 e a Convenção de Dublin, ou Sistema de Dublin, assinada em 1990. O sistema de Dublin intenta agilizar o processo de candidatura para os refugiados que procuram asilo político ao abrigo da Convenção de Genebra, que estabelece critérios para determinar o Estado-Membro responsável pela análise de um pedido de proteção internacional, em princípio, o primeiro país de entrada. Já o Tratado de Lisboa, visa a estabelecer "o princípio da solidariedade e da partilha equitativa de responsabilidades entre os Estados-Membros, incluindo as respectivas implicações financeiras", segundo Sokolska (2020, p.3).

Ainda segundo a autora: "as taxas de recolocação têm sido inferiores ao previsto e as recolocações têm sido aplicadas lentamente" (2020, p.4). Ou seja, há uma tentativa de implementação de políticas em prol dos imigrantes com destino a Europa que, porém, caminha a passos lentos na burocracia interna, e alguns países se utilizam dessas burocracias para postergar ou não ceder refúgio. Por isso, sempre é notificada nos meios de comunicação a presença de

\footnotetext{
8 Para maiores informações $\quad$ acessar $\quad$ o $\quad$ site: https://www.acnur.org/fileadmin/Documentos/portugues/BDL/Convencao_relativa_ao_Estatuto_dos_Refugiados.pd f>. Acesso em: 12/05/2020.

9 Ver no site: < https://www.publico.pt/2020/04/02/mundo/noticia/refugiados-polonia-hungria-republica-checaviolaram-lei-tribunal-europeu-1910722>. Acesso em: 11/07/2020.
} 
embarcações paradas no Mar Mediterrâneo proibidas de ancorar em portos europeus; tais empecilhos estão relacionados com a lei Non Refoulement que, segundo Oliveira, assegura:

[...] a proteção internacional dos refugiados e proíbe o Estado de acolhida de aplicar qualquer medida de saída compulsória que encaminhe o refugiado ao território onde sofra, ou possa sofrer, ameaça ou violação aos seus direitos fundamentais em virtude de perseguição, tortura ou tratamentos ou penas cruéis, desumanos ou degradantes, incluindo a proibição de repulsa contra o solicitante de refúgio que intenta permanecer sob a sua jurisdição. O princípio tem alcance, portanto, sobre o território do Estado, suas fronteiras e áreas internacionais que lhes dão acesso. (OLIVEIRA, 2017, p. 32).

A lei Non Refoulement garante aos refugiados de qualquer parte do globo o direito a pedir refúgio em qualquer outra nação. Entretanto, para isso acontecer é preciso que o solicitante esteja sofrendo algum tipo de perseguição, bem como, colocando a sua vida, liberdade ou direitos fundamentais sob ameaça de violação por questões de raça, religião, nacionalidade, pertencimento a determinado grupo social ou opinião política. Faz parte dessa lei alguns princípios excepcionais em que, por exemplo, os refugiados não podem ser extraditados para territórios terceiros. Além disso, tal lei também condena todas as espécies de instituições jurídicas que visam à saída compulsória do estrangeiro do território nacional - deportação, expulsão, extradição, entre outros. Também inclui a proibição de repulsa do estrangeiro que intenta permanecer sob a jurisdição do Estado destinado, como a rejeição de refugiados ou solicitantes de refúgio nas fronteiras e áreas internacionais que lhe dão acesso.

Essas nações que acolhem pessoas refugiadas devem assegurar-lhes o bem-estar, bem como a integridade física e psíquica dentro das leis cabíveis do seu território. Ou seja, as leis vigentes dentro de qualquer nação têm que valer para todos igualmente, sejam refugiados ou não. Em razão dos diversos contextos, o princípio de Non Refoulement é identificado como pertencente às três vertentes da proteção internacional da pessoa humana: o direito internacional dos refugiados, o direito internacional dos direitos humanos, e o direito internacional humanitário. Contudo, as potências mundiais, principalmente as que fazem mais guerras no mundo, aplicam restrições para entrada de imigrantes vindos de regiões afetadas por tais conflitos. Estas contenções de entrada, principalmente, nas grandes nações, são classificadas em:

[...] três categorias: de caráter político-institucional, expressas em políticas migratórias restritivas ao ingresso de migrantes segundo suas qualificações, ou com limitações temporais à sua permanência; de caráter físico, concretizadas em muros, cercas, faixas militarizadas nas fronteiras, zonas minadas do tipo no man's land, ou as denominadas 'territorializações' forçadas, como, por exemplo, campos de confinamento para migrantes, refugiados e solicitantes de refúgio; e de caráter cultural e ideológico, tomando o migrante por alguém 
inferior, indesejável ou ameaçador à segurança e ao bem-estar da sociedade nacional. (OLIVEIRA, 2017, p. 37)

Essas categorias promovem o preconceito e a aversão ao estrangeiro - imigrante - os quais estão imbricados em várias alegações falsas, como prejuízos econômicos dos países receptivos; aumento da violência e da prostituição nesses países e, nos dias atuais, o medo do terrorismo, concepção social fundamentada em estereótipos produzidos socialmente, reforçados pela mídia e aplicados, sobretudo, para com os povos oriundos do Oriente Médio - ou seja, estas são as contradições da migração atual.

Durante séculos, todo o Oriente Médio sofreu dois tipos principais de ataques: primeiramente, como foi citado, advindos dos grandes impérios e outras instituições ocidentais. Nota-se que, ao mesmo tempo em que essas grandes nações disputam os territórios no Oriente Médio e avançam com grandes guerras para combater supostos terroristas dentro desta região, as mesmas grandes nações tecem ideologias que desclassificam os fatores étnicos-culturais dos países alvos de dominação. Tais teorias arquitetadas no ocidente, na maioria das vezes, são implantadas por meio da cultura de massa, a qual intenta rotular, através do fenótipo, a população nativa do Oriente Médio como terrorista mediante algumas das suas produções.

Filmes como 13 Horas: os soldados secretos de benghazi (2016) do diretor Michael Bay ${ }^{10}$ e, principalmente, o filme Guerra ao terror, que ganhou o óscar de melhor filme em 2010, sob a direção de Kathryn Bigelow. ${ }^{11}$ demonstram de forma equivocada perfis terroristas. As guerras travadas contra o terrorismo em países do Oriente Médio são representadas por protagonistas ocidentais designados para a região com o intuito de libertá-la das mãos de tiranos. Todos os terroristas desses filmes são interpretados por pessoas com fenótipo árabe.

Esse tipo de mensagem reflete diretamente na forma como os ocidentais irão tratar os refugiados oriundos dessa região. Nesse contexto, Kristeva (1994, p.15) explica que "a indiferença é a carapaça do estrangeiro insensível, no fundo ele parece fora de alcance das agressões que, contudo, sente com a vulnerabilidade de medusa". Kristeva compara as sociedades que recebem os refugiados com um ser mitológico, a medusa, que tem como única fraqueza se ver no espelho. Partindo desse pressuposto, estes [ocidentais] não querem se misturar, não querem se tornar e nem querem que seus similares se tornem aquelas pessoas "terríveis" dos filmes. A autora evidencia que o medo transmitido subjetivamente pelos meios de comunicação para os ocidentais com relação aos nativos da região do Oriente Médio pode se

${ }^{10} 13$ Horas: Os Soldados Secretos de Benghazi. Filme disponível no site: < https://www.youtube.com/watch?v=gzE_QKIVynU>. Acesso em: 05/05/2020.

${ }^{11}$ Guerra ao Terror, filme disponível no: <https://www.youtube.com/watch?v=QIiIOW9nUBE>. Acesso em: $07 / 05 / 2020$ 
manifestar, muitas vezes, com violência física ou psicológica para com o imigrante. Por esse motivo, os asilados devem estar amparados sob as leis internacionais e as leis nacionais dos países que os recebem, haja vista que não é só questão de os asilar, mas também de os inserir na sociedade onde viverão.

Sabemos que a xenofobia está presente em toda sociedade, mas o ocidente criou um estigma, difundido principalmente por meio da mídia contra árabes ${ }^{12}$. Desse modo, a xenofobia torna-se um problema muito sério, uma vez que vivemos em um mundo globalizado, ou seja, a circulação de informação via internet, rádio e televisão chega a quase todas as partes do globo e, através dessas ferramentas a xenofobia está sendo difundida. Segundo Oliveira et al. (2017, p. 83), “[...] entre os 1.046.599 indivíduos entrados na Europa em 2015, metade (50,2\%) provinha da Síria." E a autora segue afirmando na mesma página que: “entre as causas destes movimentos recentes para a Europa, estão os conflitos nos países vizinhos, mas não se esgotam neles”. Em razão desses fatores, a migração causada por conflitos voltou a crescer no início do século XXI, após quase sete décadas. Parte do problema migratório é fruto de políticas perversas presentes há séculos, ou seja, são ações praticadas principalmente por forças de outras nações atuando dentro de territórios nacionais alheios com o intuito de desestabilizar estas nações e, assim, garantir as matérias primas existentes em seu interior, principalmente o petróleo que se tornou o maior símbolo das guerras na Ásia Ocidental, como já alertou Harvey (2014).

Os acontecimentos históricos evidenciam que os europeus, desde 1500, através da exploração global, via colonização, buscaram modernizar seus territórios, por meio da expropriação das riquezas dos territórios colonizados. Para Fanon (1968, p.77), “[...] em razão desta busca, umas das causas mais exitosa do continente foi a produção de milhares de cadáveres"; contudo, atualmente juntaram-se nessa procura os Estados Unidos da América, a Rússia e seus aliados poderosos. Nesse encalço, Dos Santos (2017, p.74) lança um olhar crítico quanto às políticas globais das grandes potências na contemporaneidade, observando que "os países mais modernos são os que investem com força no domínio da técnica e, somente pela violência desta, podem impor sua vontade”. Essas grandes nações mantêm guerras em quase todo o mundo e as consequências de todos esses conflitos ocasionam as grandes diásporas populacionais pelo Globo. Por exemplo, a guerra na Síria impulsionou, especialmente, o crescimento dos índices migratórios nas décadas de 2000, como vários autores referenciados nesse escrito ressaltam. Partindo desse pressuposto, Dos Santos (2017, p.74) explica que: “o burguês não altera o mundo, mas utiliza-se do mundo decaído para montar sua superestrutura”.

\footnotetext{
${ }^{12}$ Poderia citar mais estereótipos pejorativos criados sobre vários outros povos, religião e etc., mas por delimitação do tema trato somente da questão árabe.
} 
Nesse sentido, as elites das grandes nações econômicas se utilizam do legado da ciência para provocar guerras e assentar nesse mundo caótico sua superestrutura; quando na verdade podem alterar esse estado de coisas a fim de diminuir a violência e o sofrimento do ser humano.

Essas mesmas nações, apoiadas pelas elites locais, se utilizam dessas superestruturas internamente para marginalizar, estigmatizar e fomentar guerras contra outras nações ou grupos sociais tornando o mundo um caos generalizado onde todos são vítimas e ao mesmo tempo algozes. Tais fatores provocam diversos fenômenos negativos, como o aumento da migração, e consequentemente a elevação da fome, da miséria e das doenças pelo mundo. As grandes nações financiam os problemas e, por conseguinte, condenam os indivíduos oriundos das pequenas nações pelas consequências de tais atos; ou seja, as causadoras dos conflitos se beneficiam com toda essa desgraça, principalmente na venda de armas, remédios, alimentos, insumos agrícolas e, em especial, a reconstrução da infraestrutura das nações destruídas pelas guerras. Essas comercializações são feitas por poderosas corporações privadas ou estatais pertencentes às nações invasoras e poderosas que proporcionam a guerra. Vale dizer que a maior parte desse processo é legalizado em parlamentos.

O embaixador Rubens Barbosa, consultor de negócios e presidente da Rubens Barbosa \& Associados, referindo-se ao Oriente, disse: "Daqui, só temos notícia da guerra. Mas os EUA estão investindo na reconstrução da infraestrutura de países do Oriente, abrindo estradas, aumentando a produção de energia e etc.” explicou ele ao jornal Correio brasiliense (2009). Em outro ponto, o diplomata Bruno Rizzi Razente, o qual trabalhou na representação brasileira na Síria desde 2014, escreveu um artigo para o Oriente Mídias (2017) onde afirma que "espera-se um papel predominante de investimentos iranianos, russos e chineses, especialmente nos setores de energia e infra-estrutura".

Além disso, segundo o mesmo artigo, há investimentos do Banco Mundial - BM e Fundo Mundial Internacional - FMI. Uma das consequências desses problemas, segundo afirmam Spode e Rocha (2018, p.6), "é a ampliação de governos que embora com diferenças nos planos táticos ou estratégicos, se ligam aos mesmos objetivos imperialistas". Na atualidade, esse infortúnio é causado por agendas de novas políticas chamadas por Harvey (2014) de "neoconservadora", se sobrepondo ao neoliberalismo. Essas políticas neoconservadoras, como expõe o autor, acentuam os fluxos migratórios que vêm aumentando nas últimas décadas, sendo que a principal tática é implementar guerras, principalmente, no Oriente Médio, para dominar áreas petrolíferas e manter-se no poder, além de lucrar com a reconstrução da região.

David Harvey ( 2014) e Yergin ( 2012) vêm alertando que os grandes impérios estão sempre fazendo guerras e o seu único propósito corresponde é obter dinheiro e a continuação do 
poder. São essas as assertivas que estão por trás dessas invasões territoriais disfarçadas de guerra ao terror, as quais causam a espoliação de milhares de pessoas. Devo evidenciar que há outras fronteiras sangrentas na região do Oriente Médio e, também, com outros tipos de problemas, por exemplo, religiosos, étnicos etc., mas essas questões não vêm ao caso nesse artigo.

A situação da guerra síria se caracteriza da seguinte forma: por um lado o governo local tenta defender e proteger os recursos energéticos como o petróleo e o gás. Por outro, as grandes nações buscam a todo custo angariar tais recursos. Segundo Haesbaert et al. ( 2007,p.49) "“[...] a construção do território resulta da articulação de duas dimensões principais, uma mais material e ligada à esfera político-econômica, outra mais imaterial ou simbólica, ligada, sobretudo, à esfera da cultura e do conjunto de símbolos[...]”. O autor nos alerta que as causas dessas guerras não são relativas somente aos fatores econômicos, mas também culturais, ou seja, há uma tentativa de usurpar os bens materiais como, por exemplo, o petróleo e o gás natural. Nesse sentido Santos (2003, p. 47-49), afirma que: "O dinheiro é, cada vez mais, um dado essencial para o uso do território [...] a ação territorial do dinheiro global em estado puro acaba por ser uma ação cega, gerando ingovernabilidades, em virtude dos seus efeitos sobre a vida econômica e territorial". A partir das ideias de Milton Santos, é possível compreender que o dinheiro pode controlar alguns segmentos, como armas, alimentos ou a exploração das matérias primas dentro de territórios estrangeiros, ou seja, o dinheiro está atrelado a um grande jogo empresarial financeiro-capitalista. Desse modo, as grandes nações costumam gerir os seus territórios nacionais e invadir outros, por meio do dinheiro e pelo poder acima de tudo; portanto, essa é a geoestratégia primordial para invadir, tomar e gerir um território.

\section{Considerações Finais}

As grandes nações, através de suas corporações, dominam outros territórios sempre com pretextos relacionados à intervenção para manter a paz, contra ditaduras, dentre outros. Entretanto, há interesses individuais, corporativo ou coletivos via Estado. As políticas intervencionistas geram a destruição material e imaterial das pequenas nações e, consequentemente, a expropriação de pessoas pelo mundo, essencialmente, aquelas que possuem como destino as nações mais desenvolvidas financeiramente à procura de uma vida melhor e mais digna.

As intervenções militares proporcionadas pelas grandes nações causaram uma grande destruição econômica, social e cultural em todo Oriente Médio. Contudo, no momento em que alguns refugiados oriundos dessa região chegam à Europa, primeiramente, há uma grande burocracia para deixá-los se fixar. Esse fator, associado à desinformação provoca na população a 
impossibilidade de saber as causas e as consequências das guerras que as grandes nações financiam pelo mundo. Tais informações tendem sempre a ficar fora de circulação social para que a população não desperte um raciocínio crítico sobre o assunto e, assim, veja quem são os verdadeiros autores da intensificação desse fenômeno.

\section{Referências}

AFEGANISTÃO lidera crescimento do PIB. Correio Braziliense. Brasília- DF.08 de nov. 2009. Disponível em: $<$ https://www.correiobraziliense.com.br/app/noticia/economia/2009/11/08/internas_economi a,153399/afeganistao-lidera-crescimento-do-pib.shtml $>$.

BAPTISTA, Paulo Luís Antunes. Afeganistão - Uma análise Geopolítica: Reflexões sobre questões da Paz e da Guerra. Revista Militar, Portugal, n 2451, p.1-44, abril. 2006. Disponível em: $<$ https://www.revistamilitar.pt/artigo/71 >. Acesso em: 06/04/2020.

HARVEY, David. O Novo Imperialismo. 8. ed. São Paulo: Edições Loyola, 2014.

HAESBAERT, Rogério; LIMONAD, Ester. O território em tempos de globalização. GEOUERJ Revista do Departamento de Geografia, Rio de Janeiro, n. 5, p. 7-19, $1^{\circ}$ semestre de 1999. Disponível em:< https://www.e-publicacoes.uerj.br/index.php/geouerj/article/view/49049 $>$. Acessado em: 28-10-2019.

JUBILUT, Liliana Lyra. O direito internacional dos refugiados e suas aplicações no orçamento jurídico brasileiro. São Paulo: Métodos, 2007.

JUNSKOWSKI, Bruna Letícia. Síria: histórias da guerra. Universidade Federal do Paraná, Curitiba (UFPE), 2017. 76p. Trabalho de Conclusão de Curso (Curso de Comunicação Social com habilitação em Jornalismo).

KRISTEVA, Julia. Estrangeiro para nós mesmo. Rio de Janeiro: Rocco,1994.

OLIVEIRA, C. R. et al. A nova crise dos refugiados na Europa: o modelo de repulsão-atração revisitado e os desafios para as políticas migratórias. R. bras. Est. Pop, Belo Horizonte, v.34, n.1, p.73-98, abril, 2017. Disponível em: < https://www.scielo.br/scielo.php?script=sci_arttext\&pid=S0102-30982017000100073 >. Acesso em: 11/11/2019.

OLIVEIRA, Laís Gonzáles de. Barreiras fronteiriças contra o princípio de non refoulement: A inacessibilidade do território e da determinação do status de refugiado. Rev. bras. estud. Popul, Ribeirão Preto, vol.34, n.1, p.31-54, abril, 2017. Disponível em: <https://www.researchgate.net/publication/319259838_Barreiras_fronteiricas_contra_o_principi o_de non-

refoulement_a inacessibilidade_do_territorio_e_da_determinacao_do_status_de refugiado $>$. Acessado em: 06/04/2020.

RAZENTE, Bruno Rizzi. Reconstrução da Síria: Um caminho para a paz hoje. Oriente Mídia. 4 de set.2017. disponível em: <http://www.orientemidia.org/reconstrucao-da-siria-um-caminhopara-a-paz-hoje/ >

SANTOS, Milton. Por uma outra globalização: do pensamento único à consciência universal. 10. ed. Rio de Janeiro: Record, 2003. 
SANTOS, Nadson Vinicius dos. Violência e memorias: Relatos testemunhais em diálogo na África e América. Universidade Federal do Rio Grande (FURG), 2017. 237p. Tese (PósGraduação em Letras: História da Literatura).

SILVA, A.K.M. de.; SILVA, R.S.A. A Guerra na Síria e a luta pela unidade territorial. Revista de Geopolítica, Natal, v. 9, $\mathrm{n}^{\mathrm{o}}$ 1, p. 80 - 93, janeiro, 2018. Disponível em: < http://www.revistageopolitica.com.br/index.php/revistageopolitica/article/download/202/194.> Acessado em 22/03/2020.

SOKOLSKA. Ina. Política de asilo. Parlamento europeu. Estrasburgo, jan. 2020. Disponível em: < https://www.europarl.europa.eu/factsheets/pt/sheet/151/politica-de-asilo>.

SPODE, P. L. C.; ROCHA, L. H. M. Resenha do livro "O Novo Imperialismo" de David Harvey. Boletim Geográfico do Rio Grande do Sul, Porto Alegre, n. 32, p. 122-127, dez. 2018.

YERGIN, Daniel. Petróleo: Uma história mundial de conquistas, poder e dinheiro. Tradução: Leila M. U. Di Natale, Maria C. Guimarães. 4. Ed. São Paulo: Paz \& Terra, 2012.

Recebido em 24/05/2020 - Aprovado em 05/10/2020. 